UDK: 637.065

\title{
Effects of packaging materials on some ripening characteristics of Tulum cheese
}

\author{
Zekai Tarakçı*, Yusuf Durmuş \\ Food Engineering Department, Agriculture Faculty, Ordu University, Ordu, Turkey \\ Received - Prispjelo: 24.12.2015. \\ Accepted - Prihvaćeno: 20.10.2016.
}

\begin{abstract}
In this study the effects of different packaging materials on Tulum cheese made with cloth, stomach, animal skin, pot and plastic materials were investigated. Dry matter, ash, titratable acidity, salt, salt in dry matter, fat, total protein, water soluble nitrogen (WSN), trichloroacetic acid soluble nitrogen (TCA-SN), phosphotungstic acid soluble nitrogen (PTA-SN), electrophoretic casein fraction analyses, $L^{*}, a^{*}$ and $b^{*}$ values in colour analyses and sensory characteristics were analysed. Dry matter $54.74-66.37 \%$, ash $3.93-4.79 \%$, titratable acidity $1.22-1.80 \%$ as lactic acid, salt 2.48-3.93 \%, salt in the dry matter 3.78-6.20\%, fat $21-43 \%$, total protein $17.20-23.16 \%$, WSN ratio 5.58-16.81 \%, TCA-SN ratio 4.33-13.59 \%, PTA-SN ratio 2.06-5.12 \%, $\beta$-CN ratio 31.01-52.16 \%, $\alpha_{s 1}-\mathrm{CN}$ ratio $33.52-47.84 \%$, and in colour measurements $L^{*}, a^{*}$ and $b^{*}$ values ranged from 82.18-84.39, 0.93-1.72 and 8.41-16.51, respectively. Accordingly it was clarified that the use of different packaging materials affected the composition of Tulum cheese and was related to from the cheese origin as well.
\end{abstract}

Key words: Tulum cheese, packaging material, ripening characteristics

\section{Introduction}

Tulum cheese can be produced from whole, semi skimmed or non-fat sheep's, goat's, cow's or buffalo's milk or their mixture. Traditionally, Tulum cheese is made from non-fat milk remaining after butter production and sometimes yoghurt can be added to give flavour (Erdoğan et al., 2003; Gürses and Erdoğan, 2006). Tulum cheese is characterized as white or cream coloured, containing a high dry matter and protein ratio, not easily crashed, medium-hard, homogenous textured cheese with a characteristic taste which melts in the mouth revealing an easily felt original butter taste (Kurt et al., 1991). Tulum cheese is often produced from raw milk by different processing methods depending on the local dairies, farmers and production areas (Kirdar et al., 2015).
Generally, proteolysis of cheese is influenced by several factors including chymosin, $\mathrm{pH}$, moisture levels in curds, salt content, storing temperature and time. Proteolysis is probably the most important biochemical event, having a major impact on flavor and texture of most cheese varieties. Proteolysis contributes to the softening of cheese texture during ripening due to hydrolysis of the casein matrix of the cure and through a decrease in the water activity of the cure due to changes in water binding by the new carboxylic acid and amino groups formed by hydrolysis (McSweeney, 2004). The proteinases from starter and nonstarter microorganisms can also be active in degradation of cheese proteins and peptides. Lactic acid bacteria are weakly proteolytic, but possess a very comprehensive range of proteinases/peptidases capable of hydrolysing casein-derived peptides to small peptides and amino acids (Hayaloğlu et al., 
2004). Proteolysis and lipolysis are two primary processes in cheese ripening with a variety of chemical, physical, and microbiological changes taking place usually under controlled environmental conditions. Proteolysis in cheese involves a complex and dynamic series of events. In order to better understand the development of proteolysis in cheeses it is necessary to investigate the nitrogen fractions formed during ripening (McSweeney and Fox, 1993). Using that traditional method it is very difficult to produce a high quality product due to a lack of standardization of most manufacturing steps, especially the ripening conditions.

Studies on Tulum cheese are limited, although some research was focused on this variety in the past decade. These studies concentrated on the chemical and microbiological properties of Tulum cheeses sold on Turkish markets. Only few studies dealing with the effect of different packaging materials on the microbiological and chemical characteristics of Tulum cheese are available. The microbiological quality of Tulum cheeses ripened in goat's skin and polyethylene packaging materials were compared by Güven and Konar (1994). Similarly, Şengül et al. (2001) studied the effect of packaging materials (wooden box, goat's skin, stomach, class or polyethylene packaging materials) on the properties of Tulum cheese during ripening. The use of different types of milk (cow's, ewe's or goat's milk) in the manufacture of Tulum cheese was compared by Güven et al. (1995), who reported that the type of milk significantly influenced the microbiology of Tulum cheese during 210 days of ripening. Şengül and Çakmakçı (1998) used polyethylene packaging materials and wooden materials as alternatives and emphasized that the use of different packaging materials affected the chemical and microbiological quality of Tulum cheese. However, the authors recommended further studies to determine the optimal packaging material. Although raw milk continued to be used for Tulum cheese production, Bostan and Uğur (1991) and Şengül et al. (2001) recommended the use of pasteurized milk and a starter culture. Under the term "Tulum cheese" in Turkey, Erzincan Savak Tulum cheese is implied. Thus, the term "Tulum cheese" is used throughout the text to refer to Erzincan Savak Tulum cheese. Goat's skin packaging materials are stronger than sheep's skin packaging materials and Tulum cheeses are perme- able to water and air because of their porous structure. In the past, the tulum was probably used for cheese packaging because of the absence of alternative packaging materials for preserving and ripening the cheese. Nowadays, hardened plastic barrels are usually used for ripening the Tulum cheese. Since there is no standard production method, the chemical structure of the cheese is quite variable. In the past years mainly animal skin was used for packaging but it since it is expensive and due to some difficulties related to storage, easy access bins and cloth materials were also often used. The aim of this study was to investigate the physical and chemical composition of Tulum cheeses ripened in different packaging materials and determine the extent of primary and secondary proteolysis by electrophoreses.

\section{Materials and methods}

Tulum cheeses ripened in cloth, skin, pot, stomach and plastic were obtained from grocery stores and markets. In total, 20 samples were examined among which 9 were made with cloth, 2 in stomach, 4 in animal skin, 3 in pot and 2 were packaged into plastic packaging materials.

\section{Physicochemical analyses}

The cheese samples were analysed for acidity (lactic acid \%) with $0.1 \mathrm{~N} \mathrm{NaOH}$ and $\mathrm{pH}$ with a $\mathrm{pH}$ meter (Ohaus, Starter 3100), total nitrogen content using micro Kjeldahl digestion and distillation units (Velp Scientifica, Italy), salt content using the Mohr method and ash content using a muffle furnace at $550{ }^{\circ} \mathrm{C}$ for $24 \mathrm{~h}$. Fat content of cheeses was measured by Gerber method; dry matter content by weight difference using a drying oven (Nüve, Ankara, Turkey).

Nitrogen fractions of Tulum cheeses were determined using the method described by Kuchroo and Fox (1982). For preparation of water soluble extracts, $20 \mathrm{~g}$ of grated cheese was mixed with $40 \mathrm{~mL}$ of deionized water and homogenized with a homogenizer (WiseTis_HG-15D, Daihan, Korea) for $1 \mathrm{~min}$. Then it was centrifuged at $3000 \mathrm{xg}$ for $30 \mathrm{~min}$ at $4{ }^{\circ} \mathrm{C}$. The fatty layer was removed and the supernatant was filtered through Whatman 42 paper. To determine the content of water-soluble 
nitrogen (WSN), $10 \mathrm{~mL}$ of filtrate was taken and the Kjeldahl method was performed (IDF, 1993). The $12 \%$ trichloroacetic acid-soluble nitrogen (TCA$\mathrm{SN})$ fractions were prepared by mixing $25 \mathrm{~mL}$ of the WSN fraction with $25 \mathrm{~mL}$ of $24 \%(\mathrm{w} / \mathrm{v})$ TCA solution. The mixture was held at room temperature for $2 \mathrm{~h}$ and then filtered through Whatman 42 paper. The $5 \%$ phosphotungstic acid-soluble nitrogen (PTA-SN) fractions of the cheeses were prepared as follows: $3.0 \mathrm{~mL}$ of a $33 \%(\mathrm{w} / \mathrm{v})$ PTA solution and $7.0 \mathrm{~mL}$ of a $3.95 \mathrm{M} \mathrm{H}_{2} \mathrm{SO}_{4}$ solution were added to $10 \mathrm{~mL}$ of the WSN fraction. The mixture was kept at $4{ }^{\circ} \mathrm{C}$ overnight and filtered through Whatman 42 paper. The nitrogen contents were determined using the Kjeldahl method (IDF, 1993) and WSN, $12 \%$ TCA and $5 \%$ PTA values were expressed as the percentage of the total nitrogen content of the cheese (Jarrett et al., 1982).

\section{Preparation of cheese proteins and electrophoresis}

The electrophoretic analysis of protein patterns was conducted with the method given by Creamer (1991) with some modifications (Tarakçi et al., 2004). Sample buffers $(\mathrm{pH}=8.4)$ consisted of EDTA $0.0925 \mathrm{~g}$, Tris $1.08 \mathrm{~g}$, boric acid $0.55 \mathrm{~g}$ and urea $36.0 \mathrm{~g}$ were dissolved in $100 \mathrm{~mL}$. A cheese sample $(0.5 \mathrm{~g})$ was homogenized in $25 \mathrm{~mL}$ sample buffer, and then centrifuged at $3000 \mathrm{xg}$ for $30 \mathrm{~min}$; $2 \mathrm{~mL}$ of central portion was transferred into a small tube and stored at $-20^{\circ} \mathrm{C}$. Casein standard was prepared using sodium caseinate obtained from cow milk by dissolving in urea. The resolving gel buffer was prepared with Tris $9.2 \mathrm{~g}$, Urea $54 \mathrm{~g}$ and solved in $100 \mathrm{~mL}$ of distilled water, filled up to $200 \mathrm{~mL}$ ( $\mathrm{pH} 8.8$ ); $15 \mathrm{~mL}$ of $30 \%$ acrylamide/bis-acrylamide (37.5:1) solution, $35 \mathrm{~mL}$ of separating gel buffer and $15 \mu \mathrm{L}$ TEMED were used for resolving gel solution. After degassing, $70 \mu \mathrm{L}$ of ammonium persulphate (APS) solution $(0.1 \mathrm{mg} / \mathrm{L})$ was added and immediately poured into gel apparatus. A volume of $0.5 \mathrm{~mL}$ of distilled water was placed on gel solution. After polymerization of the resolving gel, water was removed and the comb was inserted. Stacking gel solution was prepared with Tris $1.08 \mathrm{~g}$, urea $36.0 \mathrm{~g}$, boric acid $0.55 \mathrm{~g}$, EDTA $0.092 \mathrm{~g}$ and $5 \mathrm{~g}$ of acrylamide/bis-acrylamide (37.5:1), and dissolved in $100 \mathrm{~mL}(\mathrm{pH}=8.4) ; 15 \mathrm{~mL}$ of this solution was taken, and $15 \mu \mathrm{L}$ of TEMED was added. After degassing, $50 \mu \mathrm{L}$ of APS was added. This solution was poured on the previous gel, and after polymerization, the comb was removed. Finally the gel was placed in the electrophoresis unit (Wealtec Bioscience Co., Ltd, Taiwan). 3 \% mercaptoethanol and $2 \%$ bromophenol blue $(0.1 \%)$ were added to frozen cheese samples; $40 \mu \mathrm{L}$ solution from cheese samples were taken and placed into the slots. Stock chamber buffer was prepared with EDTA $3.7 \mathrm{~g}$, Tris $43.2 \mathrm{~g}$ and boric acid $22 \mathrm{~g}$ and dissolved in $1 \mathrm{~L}(\mathrm{pH}=8.4)$, and the buffer was diluted with distilled water (1:4) before use. The conditions for performing electrophoresis were $\left(25 \pm 1{ }^{\circ} \mathrm{C}\right)$ maximum $280 \mathrm{~V}, 70 \mathrm{~mA}$ and $20 \mathrm{~W}$. Protein bands were stained with Coomassie BBR-250 solution (1 g of Coomassie brilliant blue R-250, $500 \mathrm{~mL}$ of isopropanol and $200 \mathrm{~mL}$ of glacial acetic acid, and dissolved in $2 \mathrm{~L}$ ). Then, bands were destained with destaining solution (200 $\mathrm{mL}$ of isopropanol and $200 \mathrm{~mL}$ acetic acid dissolved in $2 \mathrm{~L}$ ).

The gels were scanned with a scanner and pictures were transferred to the computer. Electrophoretograms by a scanner (EPSON III) were used to quantify bands using TotalLab Quant densitometry software (TotalLab Limited, Newcastle, UK), $\alpha_{\mathrm{s} 1}-\mathrm{CN}$ and $\beta-\mathrm{CN}$ were quantitatively determined by integration of peak volumes.

\section{Colour characteristics analyses}

Colour measurements were performed using a colorimeter (Minolta Chroma Meter, CR-400, Osaka, Japan). The $L^{*}, a^{*}$ and $b^{*}$ colour measurements were determined according to the CIELab colour space system, where $\mathrm{L}^{*}$ corresponded to light/dark chromaticity (changing from $0 \%$ dark to $100 \%$ light), $a^{*}$ to green/red chromaticity (changing from $-60 \%$ green to $60 \%$ red) and $b^{*}$ to blue/yellow chromaticity (changing from $-60 \%$ blue to $60 \%$ yellow). Three readings were taken for each sample and arithmetic means were calculated.

\section{Sensory analysis}

Sensory assessment of Tulum cheeses was carried out by a six-member panel of the University staff selected on the basis of interest and experience in sensory evaluation of Tulum cheeses. Prior 
to assessment, each cheese was cut into $10 \mathrm{~g}$ cubes, equilibrated to room temperature $\left(20^{\circ} \mathrm{C}\right)$ after laying for $4 \mathrm{~h}$ at room temperature and served to the panelists randomly. The overall sensory quality was assessed using a scaling method (1-10 points), where 1 reflected a very bad and 10 a very good score for appearance and colour, body and texture, flavour and acceptability. Panel members were also instructed to report any defects in colour and appearance (wet, dry, cracks), texture (hard, soft, pasty, crumbly, grainy), odour, flavour (rancid, salty, bitter, sour) and thw overall acceptability as well. Water was provided for mouth rinsing between evaluations of the samples (Tarakç1 et al., 2011).

\section{Statistical analysis}

Statistical analysis was performed using the Minitab software program (Release 16.1; Minitab, 2010). Data was analysed using the one-way analysis of variance (ANOVA) and Fisher's multiple range tests. The significance levels of $\mathrm{p}<0.05$ were used for statistical differences.

\section{Results and discussion}

\section{Physicochemical properties in Tulum cheeses}

Dry matter, acidity, salt, salt in dry matter, total protein, WSN, TCA-SN and PTA-SN values for the analysed cheese samples are given in Table 1. Dry matter contents of cloth cheeses were significantly $(p<0.05)$ higher than those of pot cheese and were followed by stomach, skin and plastic cheeses, respectively. The samples in cloth packaging had higher amounts of dry matter (66.37\%) but the lowest value of the total protein content $(17.20 \%)$ and acidity (1.22 \%). Such findings could be explained by the fact that cloth packages probably transferred water through the cloth which lead to protein losses by water. Bayar and Özrenk (2011) indicated that dry matter content was high in the Tulum cheeses packaged in skin (57.87 \%) followed by cloth $(54.92 \%)$ and plastic (53.83\%) packaged Tulum cheeses. Çakmakç1 et al. (2011) determined that goat's skin packaged Tulum cheese had $54.00 \%$ dry matter while plastic packaged Tulum cheeses had a dry matter of $48.04 \%$. Fat content of the cheese

Table 1. Chemical composition of Tulum cheeses ripened in cloth, stomach, animal skin, pot and plastic packaging materials

\begin{tabular}{cccccc}
\hline \multirow{2}{*}{ Properties } & \multicolumn{5}{c}{ Packaging material types } \\
\cline { 2 - 5 } & Cloth & Stomach & Skin & Pot & Plastic \\
\hline Dry matter (\%) & $66.37 \pm 2.06^{\mathrm{a}}$ & $61.36 \pm 7.49^{\mathrm{a}}$ & $61.96 \pm 1.31^{\mathrm{a}}$ & $65.18 \pm 9.42^{\mathrm{a}}$ & $54.74 \pm 3.47^{\mathrm{a}}$ \\
\hline Ash (\%) & $3.93 \pm 0.10^{\mathrm{a}}$ & $4.01 \pm 0.14^{\mathrm{a}}$ & $4.63 \pm 0.11^{\mathrm{a}}$ & $4.32 \pm 0.49^{\mathrm{a}}$ & $4.79 \pm 1.16^{\mathrm{a}}$ \\
\hline Titratable acidity $^{\mathrm{l}}$ & $1.22 \pm 0.11^{\mathrm{a}}$ & $1.26 \pm 0.18^{\mathrm{a}}$ & $1.62 \pm 0.07^{\mathrm{a}}$ & $1.38 \pm 0.22^{\mathrm{a}}$ & $1.80 \pm 0.54^{\mathrm{a}}$ \\
\hline pH & $5.50 \pm 0.07^{\mathrm{a}}$ & $5.23 \pm 0.30^{\mathrm{ab}}$ & $5.09 \pm 0.03^{\mathrm{b}}$ & $5.12 \pm 0.11^{\mathrm{b}}$ & $4.73 \pm 0.35^{\mathrm{b}}$ \\
\hline Salt (\%) & $2.48 \pm 0.10^{\mathrm{c}}$ & $2.98 \pm 0.18^{\mathrm{b}}$ & $3.83 \pm 0.13^{\mathrm{a}}$ & $3.93 \pm 0.14^{\mathrm{ab}}$ & $3.25 \pm 0.25^{\mathrm{b}}$ \\
\hline Salt in dry matter $(\%)$ & $3.78 \pm 0.21^{\mathrm{c}}$ & $4.90 \pm 0.31^{\mathrm{b}}$ & $6.20 \pm 0.32^{\mathrm{a}}$ & $5.35 \pm 0.52^{\mathrm{ab}}$ & $5.05 \pm 0.17^{\mathrm{ab}}$ \\
\hline Fat (\%) & $40.33 \pm 1.60^{\mathrm{a}}$ & $33.50 \pm 0.50^{\mathrm{ab}}$ & $33.25 \pm 0.63^{\mathrm{ab}}$ & $43.83 \pm 8.61^{\mathrm{a}}$ & $21.00 \pm 3.00^{\mathrm{b}}$ \\
\hline Total protein (\%) & $17.20 \pm 1.15^{\mathrm{b}}$ & $21.02 \pm 0.42^{\mathrm{ab}}$ & $23.16 \pm 2.15^{\mathrm{a}}$ & $18.59 \pm 1.68^{\mathrm{ab}}$ & $21.24 \pm 3.49^{\mathrm{ab}}$ \\
\hline WSN/TN(\%) & $9.34 \pm 1.01^{\mathrm{b}}$ & $5.58 \pm 0.15^{\mathrm{b}}$ & $16.57 \pm 1.63^{\mathrm{a}}$ & $11.56 \pm 2.97^{\mathrm{ab}}$ & $16.81 \pm 2.71^{\mathrm{a}}$ \\
\hline TCA-SN/TN $(\%)$ & $5.98 \pm 0.71^{\mathrm{b}}$ & $4.33 \pm 0.21^{\mathrm{b}}$ & $11.87 \pm 1.19^{\mathrm{a}}$ & $8.32 \pm 3.07^{\mathrm{ab}}$ & $13.59 \pm 2.67^{\mathrm{a}}$ \\
\hline PTA-SN/TN $(\%)$ & $4.47 \pm 1.28^{\mathrm{a}}$ & $2.06 \pm 0.32^{\mathrm{a}}$ & $3.83 \pm 0.09^{\mathrm{a}}$ & $3.55 \pm 1.11^{\mathrm{a}}$ & $5.12 \pm 0.45^{\mathrm{a}}$ \\
\hline
\end{tabular}

Values with different letters within the same column represent significant differences $(\mathrm{p}<0.05)$

${ }^{1}$ Titratable acidity expressed as grams of lactic acid/100 grams of cheese

WSN: Water Soluble Nitrogen, TCA-SN/TN: Trichloroacetic Acid Soluble Nitrogen,

PTA-SN/TN: Phosphotungstic Acid Soluble Nitrogen 
samples changed similarly to the dry matter contents. The observed fat contents were in the range of $21.00 \%$ and $43.83 \%$ while the highest fat content was detected in samples of pot cheeses.

The brine phenomenon and the effect of increasing the ionic strength on the structure of the casein matrix could be explained by chemical reactions occurring during brining. More precisely, when a cheese mould is placed into the brine, there is a net movement of $\mathrm{Na}^{+}$and $\mathrm{Cl}^{-}$ions from the brine into the cheese due to osmotic pressure difference between the cheese structure and the brine. Moisture in cheese diffuses out through the cheese matrix until the osmotic pressure becomes equal. The migration of salt or water is impeded by the casein matrix due to its narrow pores. The loss of water is about twice higher than the rate of $\mathrm{NaCl}$ entering, which is in proportion to their molecular sizes (Guinee and Fox, 1993; Guinee, 2004; Güven et al., 2006). In the present study it was observed that salt content of pot cheeses was higher than in all other analysed types of Tulum cheese. Çakmakçı et al. (2011) concluded that skin packaged Tulum cheeses (4.49\% in dry matter) had more salt content than plastic packaging materials (2.91\% in dry matter) Tulum cheeses. Similarly Bayar and Özrenk (2011) demonstrated the salt content of skin, plastic and cloth packaged cheeses were in descending order $3.99 \%$, $3.83 \%$ and $3.79 \%$, respectively. Analysis showed that cloth packaged Tulum cheeses had the lowest ash content while the plastic packaged Tulum cheeses had the highest ash content (Table 1). Ceylan et al. (2007) indicated that the ash contents of skin, ceramic pot and plastic packaged Tulum cheeses were $7.23 \%, 6.75 \%$ and $6.04 \%$, respectively.

Titratable acidity of plastic cheeses was higher than skin cheeses followed by pot, stomach and cloth cheese. All of the samples had a titratable acidity expressed as lactic acid below $3.0 \%$, as was specified in the regulation for Tulum cheese in Turkish standards (Anonymous, 1995). There was no statistically significant difference in the acidity values within the analysed cheese samples $(p>0.05)$. Samples in plastic containers had higher amounts of titratable acidity $(1.80 \%)$ but lowest amount of dry matter (54.74\%). Hayaloğlu et al. (2007) indicated that after 150 days of ripening plastic packaged Tulum cheeses had a titratable acidity of $0.63 \%$ and skin packaged Tulum cheeses had $0.59 \%$ and also Çakmakç1 et al. (2011) represented that plastic packaged Tulum cheeses had $1.40 \%$ and skin packaged Tulum cheeses had $1.22 \%$ titratable acidity. In another study it was expressed that Tulum cheeses obtained from grocery stores and markets had a titratable acidity of $1.07 \%$ (Morul and İşleyici, 2012). Acid development is a very important criterion in the manufacture of cheeses ripened under brine due to the inhibitory effect of lactic acid on undesirable microorganisms, and curd stability during brining (Bintsis and Papademas, 2002; Hayaloğlu et al., 2005). Titratable acidity increases and $\mathrm{pH}$ decreases due to the production of organic acids (primarily lactic acid), whereat lactic acid bacteria are mainly responsible for most of the sugar fermentation (Göncü and Alpkent, 2005). It was observed that skin packaged Tulum cheeses had the highest $\mathrm{pH}$ value while the Tulum cheeses ripened in plastic packaging materials had the lowest $\mathrm{pH}$ value (Table 1). These findings are in good agreement with the study carried out by Hayaloğlu et al., (2007). Çakmakç1 et al. (2011) pointed out that $\mathrm{pH}$ of skin packaged Tulum cheeses $(\mathrm{pH} 4.88)$ were higher than plastic packaged Tulum cheeses ( $\mathrm{pH}$ 4.72). Bayar and Özrenk (2011) presented that cloth packaged Tulum cheeses ( $\mathrm{pH}$ 5.12) had higher $\mathrm{pH}$ value than skin packaged Tulum cheeses ( $\mathrm{pH}$ 5.12).

Protein content of stomach ripened cheeses was $21.02 \%$, water-soluble protein and maturation index $5.58 \%$, salt $2.98 \%$ and salt in dry matter value was $4.90 \%$. According to the examination of cheese samples it can be said that there was no relationship between protein content and dry matter content. Although the highest protein content was determined in the cheese made with skin, lowest protein content was in cloth cheese samples and there was significant difference in terms of protein content of cheeses $(p<0.05)$. Bayar and Özrenk (2011) found that protein content of cloth, skin and plastic packaged Tulum cheeses were $24.31 \%, 22.74 \%$ and $21.67 \%$ respectively. Also Hayaloğlu et al. (2007) demonstrated that skin packaged Tulum cheeses $(21.31 \%)$ had more protein content than plastic packaged Tulum cheeses (16.71\%) and Çakmakç1 et al. (2011) found these values as $21.31 \%$ and $16.65 \%$, respectively. 
Nitrogen fractions in Tulum cheeses

The water-soluble nitrogen (WSN): Proteolysis in the cheeses throughout ripening was evaluated by analysing the proteolytic indices, including watersoluble nitrogen (WSN), trichloroacetic acid-soluble nitrogen (TCA-SN) and phosphotungstic acid-soluble nitrogen (PTA-SN). WSN resulting from the decomposition of proteins, which is an indicator of ripeness, contains high, medium and low peptides, free amino acids and nitrogen compounds produced mainly from residual rennet or proteinases present in the curd such as plasmin or proteases from the cheese microflora (McSweeney and Fox, 1997; Sousa et al., 2001; Şengül et al., 2014). Although the highest WSN values were determined in the cheese made with plastic material, lowest WSN values in stomach cheese samples and there was significant difference in terms of WSN values of cheeses $(p<0.05)$. The WSN fraction contains whey proteins, protease-peptone (soluble proteins, peptides, amino acids, amines, urea, ammonia), low molecular weight peptides $(<15000$ Dalton molecular mass) derived from casein hydrolysis (Güven et al., 2006). The soluble nitrogen compounds are mainly produced by the action of the coagulant (Roseiro et al., 2003). This indicates that the starter organisms most probably do not make a direct contribution to the WSN content in cheese (Madkor et al., 2000; Hayaloğlu et al., 2005; Cinbaş and Kılıç, 2006).
Plastic (16.81\%) and skin (16.57\%) packaged cheeses showed a high ripening degree, while stomach $(5.58 \%)$ and cloth $(9.34 \%)$ ripened cheeses showed very low levels (Table 1). Such findings are in agreement with the results of Çakmakç1 et al. (2011), who reported that there was no significant difference between the WSN contents of skin $(26.82 \%)$ and plastic (24.80\%) packaged Tulum cheeses. Şengül et al. (2014) found $18 \%$ WSN content of Tulum cheeses made with calf rennet. Ceylan et al. (2007) represented that WSN contents of skin cheeses (32.89\%) were higher than ceramic pot (30.83\%) followed by plastic (27.35\%) and these results showed considerable similarity to our findings.

The greatest part of the water- soluble nitrogen $(>64 \%)$ is consisted of nitrogen that is soluble in $12 \%$ trichloroacetic acid (TCA), which corresponds to medium and small-sized (600-15.000 Dalton molecular mass) peptides with 2-22 amino acids (Moatsou et al., 2002; Roseiro et al., 2003). It was reported that rennet, bacterial proteinases and peptidases are responsible for the formation of some $12 \%$ trichloroacetic acid-soluble nitrogen (TCA-SN) (Fox et al., 1993). TCA-SN ratios of plastic cheeses were higher than skin cheeses followed by pot, cloth and stomach cheeses, respectively (Table 1). Çakmakçı et al. (2011) reported that there was no significant difference between plastic (9.65 \%) and skin (10.99\%) packaged Tulum

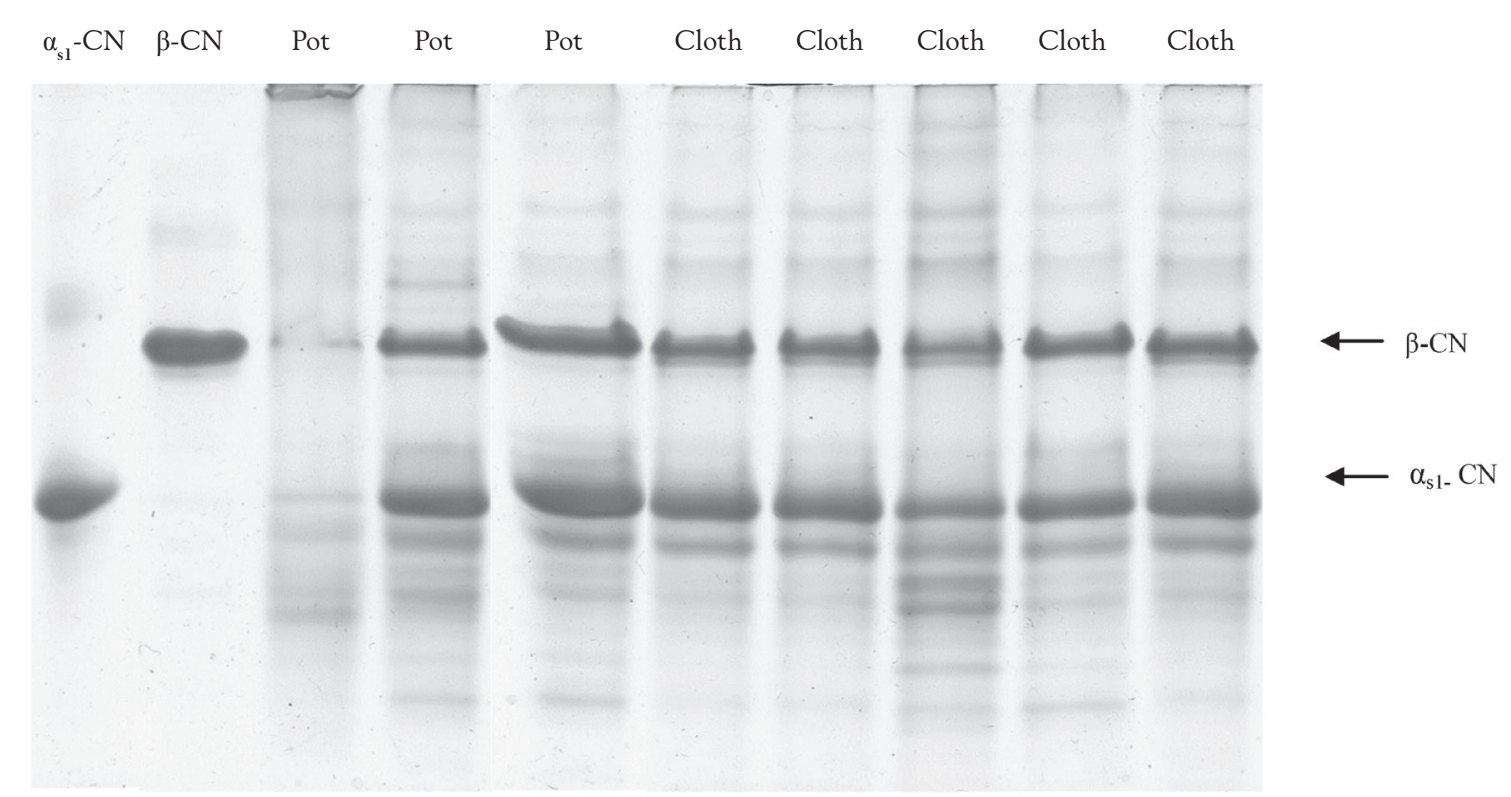

Figure 1. Ure-PAGE patterns for the caseins of pot and cloth packaged Tulum cheeses 
cheeses in terms of TCA-SN contents after 120 days of ripening and, it shows considerable similarity with our results. Şengül et al. (2014) also indicated that Tulum cheeses made with calf rennet had a TCN-SN content of about $10 \%$ after 90 days of ripening.

As proteolysis continues in cheese, relatively larger molecular weight nitrogenous fractions brought about by chymosin and cell-wall proteinases are further degraded to smaller molecular weight compounds by peptidases. The formation of amino acids and peptides with molecular weight less than 600 Dalton, which are soluble in $5 \%$ phosphotungstic acid (PTA), is strongly related to the age and flavour intensity of cheese (Moat sou et al., 2002). The phosphotungstic acid-soluble nitrogen (PTA-SN) values, which occur as a result of peptidolysis are commonly used to determine the type and the extent of proteolysis (Moatsou et al., 2002; Roseiro et al., 2003). It was observed that plastic packaged Tulum cheeses had the highest PTA-SN while the Tulum cheeses ripened in stomach packaging materials had the lowest PTA-SN (Table 1) and no significant differences were found for the PTA-SN contents ( $p>0.05)$ of the cheeses. The slight differences in PTA-SN contents can be linked to the lower moisture contents in the cheeses ripened in packages. Çakmakçı et al. (2011) stated that there was no significant difference between skin (4.64 \%) and plastic $(4.13 \%)$ packaged Tulum cheeses.

\section{Electrophoretical analysis in Tulum cheeses}

The ratios of $\beta-\mathrm{CN}$ and $\alpha_{\mathrm{s1}}-\mathrm{CN}$ for Tulum cheeses are presented in Table 2. As it can be seen there is no statistical difference between $\alpha_{s 1}-\mathrm{CN}$ ratios $(p>0.05)$ while the ratio of $\beta-C N$ was higher in the cheeses packaged in pot and plastic. The extent of degradation of major caseins and their hydrolysis products was determined by the UreaPAGE. Figure 1 and Figure 2 shows the electrophoretical analyses of the $\alpha_{\mathrm{s} 1}-\mathrm{CN}$ and $\beta-\mathrm{CN}$ fractions and other breakdown products of experimental cheeses. $\alpha_{\mathrm{s} 1}-\mathrm{CN}$ was observed with a high intensity at the end of ripening. The highest density of $\alpha_{s 1}-C N$ was found in cheese produced in plastic package. The highest $\alpha_{s 1}$-CN degradation was observed in cheeses made with skin packaging material followed by pot and plastic. Such results may be attributed to the high drop of $\mathrm{pH}$ for skin, pot and plastic packaged cheeses. Another reason of higher degradation rate of $\alpha_{\mathrm{s} 1}-\mathrm{CN}$ in skin, pot and plastic packaged cheeses may be the enhanced activity of nonstarter bacteria, depending on the decrease of $\mathrm{pH}$ in these cheeses. Different findings about $\alpha_{\mathrm{s} 1}$-CN degradation rate in literature are possible because of the differences of milk used, manufacturing procedure and ripening conditions (Fox et al., 1993).

It was established that $\beta$-CN was more resistant to proteolysis, especially in the cheese matrix, either by calf rennet or starter enzymes, owing to

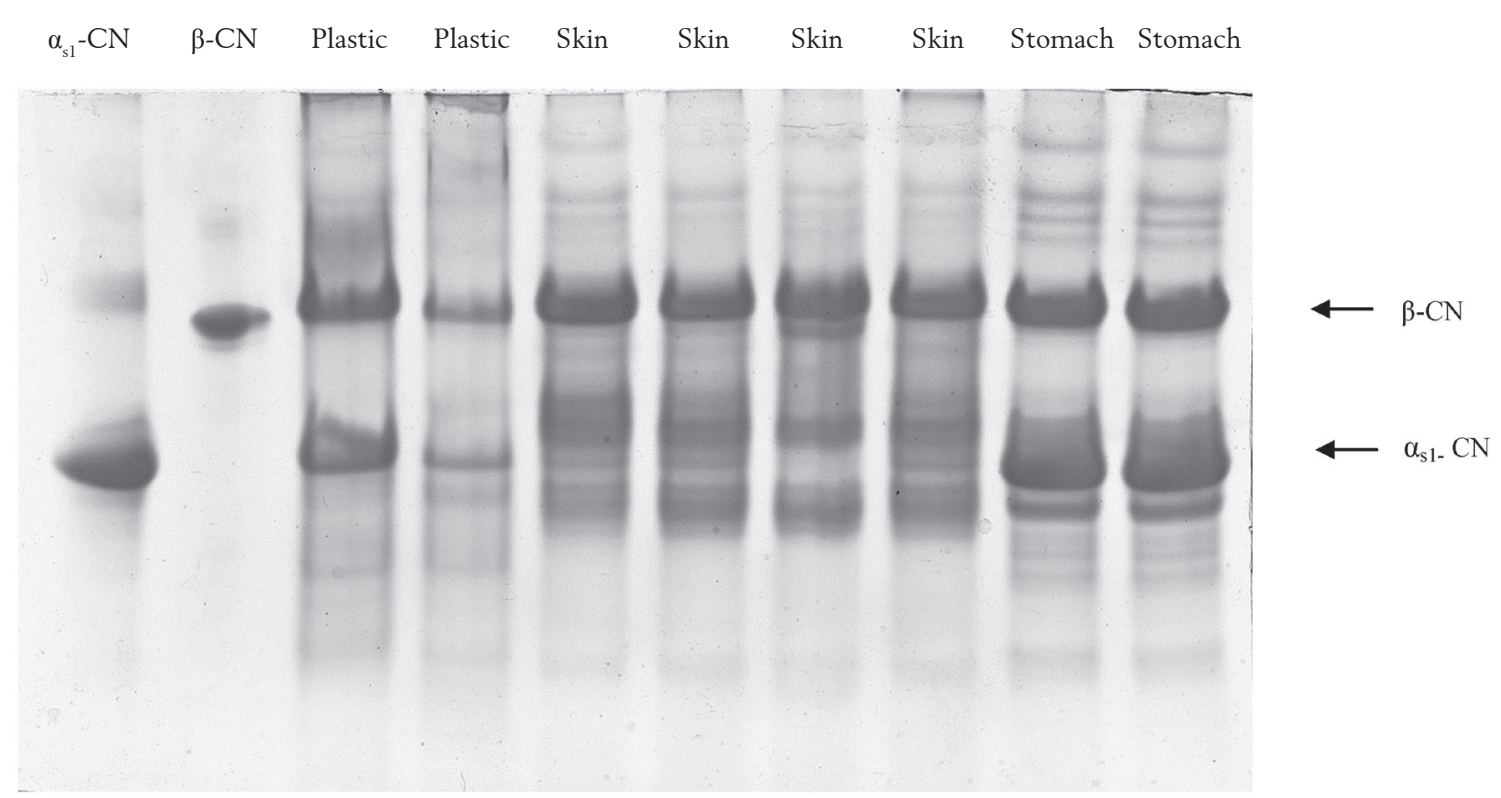

Figure 2. Ure-PAGE patterns for the caseins of plastic, skin and stomach packaged Tulum cheeses 
its structure and particularly, its tendency to associate. Plasmin, an alkaline milk protease, plays a major role in proteolysis (Stepaniak, 2004). Plasmin dissociates from casein micelles as the $\mathrm{pH}$ decreased (Yazıcı and Dervişoğlu, 2003) and its activity increases in the cheese (Fox et al., 1993). Breakdown of $\beta$-casein in cheeses ripened in plastic and pot materials was higher than others. The progress of the $\beta-C N$ degradation in the present study was in agreement with the findings of Poveda et al. (2003), White et al. (2003) and Hayaloğlu et al. (2005). Metin (2014) stated that the percentage of $\alpha_{\mathrm{s}}-\mathrm{CN}$ was $43 \%$ and $\beta$-CN $27 \%$ in cow milk. It can be seen from the Table 2 that the percentage of $\alpha_{\mathrm{s} 1}-\mathrm{CN}$ was less than $\beta-\mathrm{CN}$ in the cheeses of skin, pot and plastic. High degradation of $\alpha_{\mathrm{s} 1}$-caseins was observed which implies a high ripening degree of these samples. Such results were very similar to WSN and TCA-SN contents of cheese samples shown in Table 1. Some weak bands were also observed in the region of $\gamma-\mathrm{CN}$ in stomach packaged cheeses. Densitometric evaluations of the electrophoretograms implied significant difference for $\beta-\mathrm{CN}$ concentrations between stomach and plastic packaged Tulum cheeses (Table 2). Şengül et al. (2014) reported that breakdown of $\alpha_{\mathrm{s} 1}-\mathrm{CN}$ and $\beta-\mathrm{CN}$ was higher in Tulum cheeses made with of Aspergillus niger and Rhizomucor miehei than in cheeses made with calf rennet.

Table 2. $\beta-\mathrm{CN}$ and $\alpha_{\mathrm{s} 1}-\mathrm{CN}$ Tulum cheeses ripened in cloth, stomach, animal skin, pot and plastic packaging materials

\begin{tabular}{ccccccc}
\hline \multirow{2}{*}{ Casein } & \multicolumn{6}{c}{ Packaging material types } \\
\cline { 2 - 6 } & Cloth & Stomach & Skin & Pot & Plastic & Mean \\
\hline$\beta-\mathrm{CN}(\%)$ & $36.18 \pm 2.05^{\mathrm{ab}}$ & $31.01 \pm 0.69^{\mathrm{b}}$ & $39.10 \pm 4.81^{\mathrm{ab}}$ & $43.32 \pm 9.96^{\mathrm{ab}}$ & $52.16 \pm 0.97^{\mathrm{a}}$ & $49.60 \pm 2.52^{\mathrm{A}}$ \\
\hline$\alpha_{\mathrm{s1}} \mathrm{CN}(\%)$ & $40.18 \pm 4.65^{\mathrm{a}}$ & $45.87 \pm 0.56^{\mathrm{a}}$ & $34.62 \pm 2.91^{\mathrm{a}}$ & $40.50 \pm 3.24^{\mathrm{a}}$ & $47.84 \pm 0.97^{\mathrm{a}}$ & $40.69 \pm 2.07^{\mathrm{A}}$ \\
\hline
\end{tabular}

Means within same row followed by different lowercase letters represent significant differences $(\mathrm{p}<0.05)$

Means within same column followed by different uppercase letters represent significant differences $(\mathrm{p}<0.05)$

Table 3. Color values of Tulum cheeses ripened in cloth, stomach, animal skin, pot and plastic packaging materials

\begin{tabular}{cccccc}
\hline \multirow{2}{*}{ Variable } & \multicolumn{5}{c}{ Packaging material types } \\
\cline { 2 - 5 } & Cloth & Stomach & Skin & Pot & Plastic \\
\hline$L^{*}$ & $83.62 \pm 0.67^{\mathrm{a}}$ & $83.13 \pm 2.74^{\mathrm{a}}$ & $82.18 \pm 0.95^{\mathrm{a}}$ & $83.58 \pm 0.57^{\mathrm{a}}$ & $84.39 \pm 2.17^{\mathrm{a}}$ \\
\hline$a^{*}$ & $0.93 \pm 0.19^{\mathrm{a}}$ & $1.72 \pm 0.13^{\mathrm{a}}$ & $0.74 \pm 0.32^{\mathrm{a}}$ & $1.31 \pm 0.47^{\mathrm{a}}$ & $1.45 \pm 0.82^{\mathrm{a}}$ \\
\hline$b^{*}$ & $16.51 \pm 1.30^{\mathrm{a}}$ & $8.41 \pm 1.33^{\mathrm{b}}$ & $9.73 \pm 1.04^{\mathrm{b}}$ & $9.58 \pm 0.62^{\mathrm{b}}$ & $9.96 \pm 2.94^{\mathrm{b}}$ \\
\hline
\end{tabular}

Means with different letters within the same column represent significant differences $(\mathrm{p}<0.05)$

Table 4. Sensory characteristics of Tulum cheeses ripened in cloth, stomach, animal skin, pot and plastic packaging materials

\begin{tabular}{cccccc}
\hline \multirow{2}{*}{ Variable } & \multicolumn{5}{c}{ Packaging material types } \\
\cline { 2 - 5 } & Cloth & Stomach & Skin & Pot & Plastic \\
\hline Color and Appearance & $7.83 \pm 0.83^{\mathrm{a}}$ & $6.67 \pm 0.62^{\mathrm{a}}$ & $8.33 \pm 0.56^{\mathrm{a}}$ & $7.17 \pm 1.01^{\mathrm{a}}$ & $7.83 \pm 0.48^{\mathrm{a}}$ \\
\hline Texture & $8.00 \pm 0.93^{\mathrm{a}}$ & $7.33 \pm 0.72^{\mathrm{a}}$ & $7.67 \pm 0.76^{\mathrm{a}}$ & $7.00 \pm 0.93^{\mathrm{a}}$ & $8.00 \pm 0.37^{\mathrm{a}}$ \\
\hline Odour & $7.83 \pm 0.87^{\mathrm{a}}$ & $6.83 \pm 0.95^{\mathrm{a}}$ & $7.00 \pm 0.63^{\mathrm{a}}$ & $8.00 \pm 1.13^{\mathrm{a}}$ & $7.50 \pm 0.43^{\mathrm{a}}$ \\
\hline Flavour & $9.50 \pm 0.29^{\mathrm{a}}$ & $8.25 \pm 0.48^{\mathrm{ab}}$ & $8.00 \pm 0.58^{\mathrm{b}}$ & $9.25 \pm 0.48^{\mathrm{ab}}$ & $8.25 \pm 0.25^{\mathrm{ab}}$ \\
\hline Overall acceptability & $8.17 \pm 0.95^{\mathrm{a}}$ & $7.33 \pm 0.80^{\mathrm{a}}$ & $7.50 \pm 0.67^{\mathrm{a}}$ & $7.33 \pm 1.02^{\mathrm{a}}$ & $7.50 \pm 0.76^{\mathrm{a}}$ \\
\hline
\end{tabular}

Values with different letters within the same column represent significant differences $(\mathrm{p}<0.05)$ 


\section{Colour measurements in Tulum cheeses}

Colour is one of the most important visual attributes in food. Quality assessment of colour may include analytical or sensory measures. $L^{*}$ value is an estimation of food whiteness while $a^{*}$ value is an indicator of redness. The $b^{*}$ value is a measure of yellowness to blueness of the product. $L^{*}, a^{*}$ and $b^{*}$ values are shown in Table 3. According to the performed colour measurements no significant differences were noted among the experimental cheeses regarding the $L^{*}$ and $a^{*}$ values $(\mathrm{p}>0.05)$. However, plastic cheese had higher $L^{*}$ values than cloth, pot, stomach and skin cheeses packaging material did not significantly affect the $L^{*}$ value $(\mathrm{p}>0.05)$. Material types significantly $(\mathrm{p}<0.05)$ affected on the yellowness. Cloth type cheese samples showed the highest $b^{*}$ values while the lowest values were detected for stomach cheese samples. Such results were in good agreement with findings of Dufossé et al. (2005) for soft cheeses. Tarakç1 et al. (2011) found $L^{*}$, $a^{*}$, and $b^{*}$ values after 90 days ripening as 85.80 , -2.89 and 27.53 , respectively. In another research $L^{*}$ values ranged from 82.71 to 88.80 and $b^{*}$ values ranged from 7.90 to 14.19 on tulum cheeses produced from raw goat milk (Sert et al., 2014).

\section{Sensory evaluation in Tulum cheeses}

Sensory analysis is considered as an important technique to determine product quality. The first impression offood is usually visual, and a major part of the consumer's acceptance of food depends on its appearance. Often if the appearance is unattractive, a potential consumer may never experience other attributes such as flavor and texture. The appearance of foodstuffs is the only permitted way to evaluate food products. With respect to that, colour is a clue for many qualities of food such as flavour, naturalness or maturity, and drives consumers' choices. Sensory characteristics of the Tulum cheeses are presented in Table 4. However, there was no significant differences among cheese samples panelists assigned high scores on skin packaged Tulum cheeses. Cloth packaged Tulum cheeses had high scores regarding as texture, flavour and overall acceptability. Panelists assigned lowest odour scores to samples prepared with Stomach package. As similar to the present study Çakmakçı et al. (2011) indicated that skin pack- aged Tulum cheeses had higher scores of appearance than plastic cheeses. Ceylan et al. (2007) found that skin packaged Tulum cheeses had the highest scores of texture followed by ceramic pot and plastic while ceramic pot remarked as the highest values of flavour, odour and overall acceptability followed by skin and plastic packaging materials. Bayar and Özrenk (2011) demonstrated that Tulum cheeses packaged in skin had higher colour scores than plastic and cloth packaged Tulum cheeses.

\section{Conclusions}

Packaging materials used for ripening medium lead to have large differences in the psychochemical composition of Tulum cheeses. However, ripening was found to be extremely effective regarding the quality of the overall cheese manufacturing techniques and storage conditions. The selling points where Tulum cheese samples were submitted to consumption and package materials affected the quality of the product. The use of different packaging materials in the manufacture of Tulum cheese showed to significantly influence the ripening process of Tulum cheese. The ripening index values of the cheeses ripened in skin and plastic materials were higher than those ripened in cloth, animal stomach and pot materials. In addition, it was observed that the quality aspects of Tulum cheese were firmly related to nonstandard producing techniques, ripening and different storing places. It could be concluded that all of the analysed Tulum cheese samples had different compositions because they originated from different producers. In order to obtain a standard product all the producers should use same process method and packaging material samples.

\section{Acknowledgement}

The present study has been supported by a grant from Ordu University Scientific Research Fund for the financial support of this project (Project No: AR-1313). 


\section{Utjecaj različitih načina pakiranja na neke parametre zrenja sira Tulum}

\section{Sažetak}

U ovom je radu istraživan utjecaj različitih načina pakiranja (sirna marama, mišina, životinjska koža, tegla i plastična ambalaža) na Tulum sir. U svim ispitivanim uzorcima sira određivan je udio suhe tvari, pepeo, titracijska kiselost, udio soli i udio soli u suhoj tvari, udio masti, udio proteina, količina dušika topljivog u vodi (WSN), količina dušika topljivog $\mathrm{u}$ trikloroctenoj kiselini (TCA-SN), količina dušika topljivog $\mathrm{u}$ fosfor-tungastičnoj kiselini (PTA), te je načinjena elektroforetska analiza kazeinskih frakcija kao i analiza boje izražene preko $L^{*}, a^{*} \mathrm{i} b^{*}$ vrijednosti. Udio suhe tvari kretao se u rasponu 54,74-66,37 \%, pepeo 3,93-4,79 \%, titracijska kiselost izražena kao \% mliječne kiseline 1,22-1,80 \%, udio soli 2,48-3,93 \%, udio soli u suhoj tvari 3,78-6,20\%, masti $21-43 \%$, udio proteina $17,20-23,16 \%$, količina WSN 5,58-16,81 \%, količina TCA-SN 4,33-13,59 \%, količina PTA-SN 2,06-5,12 \%, omjer frakcija $\beta$-CN 31,01-52,16\%, omjer frakcija $\alpha_{s 1}-\mathrm{CN} 33,52-47,84 \%$. Analize čimbenika boje rezultirale su vrijednostima $L^{*}, a^{*}$ i $b^{*}$ u rasponu $82,18-84,39$, 0,93-1,72 i 8,41-16,51. Sukladno tomu, može se zaključiti da je upotreba različitih ambalažnih materijala utjecala na sastav Tulum sira, a koji je također bio usko vezan uz podrijetlo sira.

\section{Ključne riječi: Tulum sir, ambalažni materijal, karakteristike zrenja}

\section{References}

1. Anonymous (1995): Turkish Standard, Standard of white-brined cheese TS 591, Turkish Standards Institute, Ankara, Turkey.

2. Bayar, N., Özrenk, E. (2011): The effect of quality properties on Tulum cheese using different package materials, African Journal of Biotechnology 10, 1393-1399.

3. Bintsis, T., Papademas, P. (2002): Microbiological quality of white brined cheeses: a review, International Journal of Dairy Technology 55, 113-120. doi: 10.1046/j.1471-0307.2002.00054.x

4. Bostan, K., Uğur, M. (1991): Tulum peynirinde starter kültür kullanim olanakları. II. Uluslararasi Gıda Sempozyumu, Uludag University, Bursa, Turkey 17, 97-110.
5. Ceylan, Z.G., Çağlar, A., Çakmakçı, S. (2007): Some physicochemical, microbiological, and sensory properties of tulum cheese produced from ewe's milk via a modified method, International Journal of Dairy Technology 60, 191-197. doi: 10.1111/j.1471-0307.2007.00326.x

6. Cinbas, T., Kılıç, M. (2006): Proteolysis and lipolysis in White cheeses manufactured by two different production methods, International Journal of Food Science \& Technology 41, 530-537. doi: 10.1111/j.1365-2621.2005.01102.x

7. Creamer, L.K. (1991): Electrophoresis of cheese, Bulletin-International Dairy Federation 14-28.

8. Çakmakçı, S., Gürses, M., Gündoğdu, E. (2011): The effect of different packaging materials on proteolysis, sensory scores and gross composition of tulum cheese, African Journal of Biotechnology Vol. 10 (21), 4444-4449.

9. Dufossé, L., Galaup, P., Carlet, E., Flamin, C., Valla, A. (2005): Spectrocolorimetry in the CIE L a b color space as useful tool for monitoring the ripening process and the quality of PDO red-smear soft cheeses, Food Research International 38, 919-924. doi: 10.1016/j.foodres.2005.02.013

10. Erdoğan, A., Gürses, M., Sert, S. (2003): Isolation of moulds capable of producing mycotoxins from blue mouldy Tulum cheeses produced in Turkey, International Journal of Food Microbiology 85, 83-85. doi: 10.1016/S0168-1605(02)00485-3

11. Fox, P.F., Law, J., McSweeney, P.L.H., Wallace, Jt. (1993): Biochemistry of cheese ripening. In Cheese: chemistry, physics and microbiology, Springer, 389-438. doi: 10.1007/978-1-4615-2650-6_10

12. Göncu, A., Alpkent, Z. (2005): Sensory and chemical properties of white pickled cheese produced using kefir, yoghurt or a commercial cheese culture as a starter, International Dairy Journal 15, 771-776. doi: 10.1016/j.idairyj.2004.10.008

13. Guinee, T.P. (2004): Salting and the role of salt in cheese, International Journal of Dairy Technology 57, 99-109. doi: 10.1111/j.1471-0307.2004.00145.x

14. Guinee, T.P., Fox, P.F. (1993): Cheese: Chemistry, Physics and Microbiology, General Aspects, Ed. Fox, P.F. Vol. 1, 257-302. doi: 10.1007/978-1-4615-2650-6_7

15. Gurses, M., Erdogan, A. (2006): Identification of lactic acid bacteria isolated from Tulum cheese during ripening period, International Journal of Food Properties 9, 551-557. doi: 10.1080/10942910600596126

16. Güven, M., Konar, A. (1994): İnek sütlerinden üretilen ve farklı ambalajlarda olgunlaştırılan tulum peynirlerinin mikrobiyolojik özellikleri, Gıda Dergisi 19,

17. Güven, M., Konar, A., Kleeberger, A. (1995): İnek, koyun ve keçi sütlerinden üretilen ve deri tulumlarda farklı sürelerde olgunlaştırılan Tulum peynirlerinin bazı mikrobiyolojik özelliklerinin saptanması üzerinde karşılaştırmalı bir araştırma, J. Agric. For 19, 293-298.

18. Güven, M., Yerlikaya, S., Hayaloğlu, A.A. (2006): Influence of salt concentration on the characteristics of Beyaz cheese, a Turkish white-brined cheese, Lait 86, 73-82. doi: 10.1051/lait:2005043 
19. Hayaloğlu, A.A., Çakmakçı, S., Brechany, E.Y., Deegan, K.C., McSweeney, P.L.H. (2007): Microbiology, biochemistry, and volatile composition of Tulum cheese ripened in goat's skin or plastic bags, Journal of Dairy Science 90, 1102-1121. doi: 10.3168/jds.S0022-0302(07)71597-7

20. Hayaloğlu, A.A., Güven, M., Fox, P.F., Hannon, J.A., McSweeney, P.L.H. (2004): Proteolysis in Turkish White-brined cheese made with defined strains of Lactococcus, International Dairy Journal 14, 599-610. doi: 10.1016/j.idairyj.2003.12.008

21. Hayaloğlu, A.A., Güven, M., Fox, P.F., McSweeney, P.L.H. (2005): Influence of starters on chemical, biochemical, and sensory changes in Turkish White-brined cheese during ripening, Journal of Dairy Science 88, 3460-3474. doi: 10.3168/jds.S0022-0302(05)73030-7

22. International Dairy Federation (IDF) (1993): Milk. Determination of the nitrogen (Kjeldahl method) and calculation of the crude protein content. IDF Standard 20B. IDF, Brussels, Belgium.

23. Jarrett, W.D., Aston, J.W., Dulley, J.R. (1982): A simple method for estimating free amino acids in Cheddar cheese, Australian Journal of Dairy Technology (Australia).

24. Kirdar, S.S., Kose, Ş., Gun, İ., Ocak, E., Kursun, Ö. (2015): Do consumption of Kargi Tulum cheese meet daily requirements for minerals and trace elements? Mljekarstvo 65 (3), 203-209. doi: 10.15567/mljekarstvo.2015.0307

25. Kuchroo, C.N., Fox, P.F. (1982): Soluble nitrogen in Cheddar cheese: comparison of extraction procedures, Milchwissenschaft 37, 331-335.

26. Kurt, A., Çakmakçı, S., Çağlar, A., Akyüz, N. (1991): Erzincan Tulum (Şavak) Peynirinin Yapılışı, Duyusal, Fiziksel ve Kimyasal Özellikleri Üzerinde bir Araştırma. Gıda Dergisi 16.

27. Madkor, S.A., Tong, P.S., El Soda, M. (2000): Ripening of Cheddar cheese with added attenuated adjunct cultures of lactobacilli, Journal of Dairy Science 83, 1684-1691. doi: 10.3168/jds.S0022-0302(00)75037-5

28. McSweeney, P.L.H. (2004): Biochemistry of cheese ripening, International Journal of Dairy Technology 57, 127-144. doi: 10.1111/j.1471-0307.2004.00147.x

29. McSweeney, P.L.H., Fox, P.F. (1993): Cheese: methods of chemical analysis. In Cheese: Chemistry, physics and microbiology, Springer, 341-388. doi: 10.1007/978-1-4615-2650-6_9

30. McSweeney, P.L.H., Fox, P.F. (1997): Chemical methods for the characterization of proteolysis in cheese during ripening, Le lait 77, 41-76. doi: 10.1051/lait:199713

31. Metin, M. (2014): Süt teknolojisi: sütün bileşimi ve işlenmesi. Ege Üniversitesi.

32. Moatsou, G., Massouras, T., Kandarakis, I., Anifantakis, E. (2002): Evolution of proteolysis during the ripening of traditional Feta cheese, Le Lait 82, 601-611. doi: 10.1051/lait:2002036

33. Morul, F., İşleyici, Ö. (2012): Divle Tulum Peynirinin Kimyasal ve Mikrobiyolojik Özellikleri, YYU Veteriner Fakultesi Dergisi 23, 71-76.
34. Poveda, J.M., Sousa, M.J., Cabezas, L., McSweeney, P.L.H. (2003): Preliminary observations on proteolysis in Manchego cheese made with a defined-strain starter culture and adjunct starter (Lactobacillus plantarum) or a commercial starter, International Dairy Journal 13, 169-178. doi: 10.1016/S0958-6946(02)00150-4

35. Roseiro, L. B., Garcia-Risco, M., Barbosa, M., Ames, J.M., Wilbey, R.A. (2003): Evaluation of Serpa cheese proteolysis by nitrogen content and capillary zone electrophoresis, International Journal of Dairy technology 56, 99-104. doi: 10.1046/j.1471-0307.2003.00079.x

36. Sert, D., Akin, N., Aktumsek, A. (2014): Lipolysis in Tulum cheese produced from raw and pasteurized goats' milk during ripening, Small Ruminant Research 121, 351-360. doi: 10.1016/j.smallrumres.2014.06.006

37. Sousa, M.J., Ardö, Y., McSweeney, P.L.H. (2001): Advances in the study of proteolysis during cheese ripening, International Dairy Journal 11, 327-345. doi: 10.1016/S0958-6946(01)00062-0

38. Stepaniak L (2004): Dairy enzymology, International Journal of Dairy Technology 57, 153-171. doi: 10.1111/j.1471-0307.2004.00144.x

39. Şengül, M., Çakmakçı, S. (1998): Erzincan Tulum (Savak) peynirinin bazi kalite kriterleri uzerine ambalaj materyali ve olgunlasma suresinin etkisi. Dogu Anadolu Tarim Kongresi, Ataturk University, Erzurum, Turkey 1687-1698.

40. Şengül, M., Erkaya, T., Dervişoğlu, M., Aydemir, O.O., Gül, O., Dervişoğlu, M., Aydemir, O.O., Gül, O. (2014): Compositional, biochemical and textural changes during ripening of Tulum cheese made with different coagulants, International Journal of Dairy Technology 67, 373-383. doi: 10.1111/1471-0307.12120

41. Şengül, M., Türkoğlu, H., Çakmakçı, S., Çon, A.H. (2001): Effect of casing materials and ripening period on some microbiological properties of Tulum cheese, Pakistan J. Biol. Sci 4, 854-857. doi: 10.3923/pjbs.2001.854.857

42. Tarakç1, Z., Coşkun, H., Tunçtürk, Y. (2004): Some Properties of Fresh and Ripened Herby Cheese, a Traditional Variety Produced in Turkey, Food Technology and Biotechnology 42, 47-50.

43. Tarakçı, Z., Temiz, H., Aykut, U., Turhan, S. (2011): Influence of wild garlic on color, free fatty acids, and chemical and sensory properties of herby pickled cheese, International Journal of Food Properties 14, 287-299. doi: 10.1080/10942910903176576

44. White, S.R., Broadbent, J.R., Oberg, C.J., McMahon, D.J. (2003): Effect of Lactobacillus helveticus and Propionibacterium freudenrichii ssp. shermanii combinations on propensity for split defect in Swiss cheese, Journal of Dairy Science 86, 719-727. doi: 10.3168/jds.S0022-0302(03)73652-2

45. Yazıc1, F., Dervişoğlu, M. (2003): Effect of pH adjustment on some chemical, biochemical, and sensory properties of Civil cheese during storage, Journal of Food Engineering 56, 361-369. doi: 10.1016/S0260-8774(02)00208-X 